\title{
Atypical presentations of celiac disease
}

\author{
${ }^{1}$ Emergency Clinical Hospital of Constanta County \\ ${ }^{2}$ Pediatric Department, Faculty of Medicine, University "Ovidius", Constanta
}

\begin{abstract}
In this study we evaluated the association of celiac disease in 81 children with autoimmune disease and genetic syndromes over a two years periods (January 2014 to July 2016) in Pediatric Clinic in Constanta. Because the extraintestinal symptoms are an atypical presentation of celiac disease we determined in these children the presence of celiac disease antibodies: Antitissue Transglutaminase Antibody $\operatorname{IgA}$ and $\operatorname{IgA}$ total serum level as a screening method followeds in selective cases by Anti-tissue Transglutaminase Antibody IgG, anti-endomysial antibodies, deamidated gliadin antibodies IgA and IgG and intestinal biopsia. In our study 8 patients had been diagnosed with celiac disease with extraintestinal symptoms, of which 4 with type 1 diabetes, 1 patient with ataxia, 2 patients with dermatitis herpetiformis and 1 patient with Down syndrome that associate also autoimmune thyroiditis, alopecia areata, enamel hypoplasia.
\end{abstract}

Keywords : celiac disease, children, atypical presentation

\section{Corina Elena Frecus}

31 Dorobantilor Street, Eforie Nord, Constanta, Romania

email : frecuscorina@yahoo.com

phone: +40752232559
Introduction

Introduction . Celiac disease is an autoimmune disorder that occurs in people with genetic predisposition, which may present numerous extraintestinal symptoms and connections with other autoimmune diseases and genetic syndromes The disorder is now considered the result of a complex interplay of intrinsic (genetic) and variable extrinsic (environmental) factors that explain the wide spectrum of clinical manifestations ranging from asymptomatic to severe malabsorption[1].

Some of these extraintestinal symptoms are the direct consequences of autoimmunity: alopecia areata, ataxia, autoimmune thyroiditis, dermatitis herpetiformis, type 1 diabetes.

Because the extraintestinal symptoms are an atypical presentation of celiac disease, there is a risk to misdiagnose this disease. Long-standing untreated celiac disease, even if clinically silent, predisposes for other autoimmune diseases. Gluten-free diet is the standard treatment and we will see its effect on some of the extraintestinal symptoms[1,2]. 
During January 2014 to July 2016 in Pediatric Clinic in Constanta were evaluated 81 children, of which 75 patients diagnosed with autoimmune disease and genetic syndromes, from risk group for celiac disease and 6 patients with extraintestinal symptoms like ataxia and dermatitis herpetiformis.

From group of autoimmune diseases and genetic syndromes were evaluated: 61 patients with type 1 diabetes, 6 patients with Down Syndrome, 2 patients with Turner Syndrome, 4 patients with autoimmune thyroiditis and 2 patients with selective IgA deficiency.

We evaluated the presence of antibodies: Antitissue Transglutaminase Antibody IgA and IgG, antiendomysial antibodies, deamidated gliadin antibodies IgA and IgG.

\section{Results and discussions}

8 patients had been diagnosed with celiac disease with extraintestinal symptoms, of which 4 with type 1 diabetes (Table I), 1 patient with ataxia, 2 patients with dermatitis herpetiformis and 1 patient with Down syndrome that associate also autoimmune thyroiditis, alopecia areata, enamel hypoplasia.

After we completed the growth charts, we observed that $25 \%$ of children had weight on $\mathrm{P} 3 \%$ and $75 \%$ with weight under P3\% (Figure 1).

Type 1 diabetes and celiac disease share common genetic origins and predisposition factors in the onset of clinical symptoms. Celiac disease appears 20 times more frequently in persons with type 1 diabetes compared with general population [3]. The onset of diabetes under the age of 4 years is an increased risk for associated celiac disease [4]. 


\begin{tabular}{|l|c|c|c|c|}
\hline Stg MARSH & IIIc & IIIc & I & 0 \\
& & & & Preinfiltrative \\
\hline
\end{tabular}

Non-digestive symptoms of celiac disease like dermatitis herpetiformis have been identified in 2 patients (Table II, Figure 2).

Table II. Pacients with celiac diseses and dermatitis herpetiformis

\begin{tabular}{|l|l|l|}
\hline Patient & G.R & P.O. \\
\hline Age & $\begin{array}{l}6 \text { years and } 5 \\
\text { months }\end{array}$ & $\begin{array}{l}5 \text { years and } 6 \\
\text { months }\end{array}$ \\
\hline Sex & M & F \\
\hline $\begin{array}{l}\text { Anti-tissue } \\
\text { Transglutaminase } \\
\text { antibody IgA }\end{array}$ & $>200 \mathrm{U} / \mathrm{ml}$ & $>200 \mathrm{U} / \mathrm{ml}$ \\
\hline $\begin{array}{l}\text { Anti-tissue } \\
\text { Transglutaminase } \\
\text { antibody IgG }\end{array}$ & $105.8 \mathrm{U} / \mathrm{ml}$ & $151.1 \mathrm{U} / \mathrm{ml}$ \\
\hline $\begin{array}{l}\text { Anti-endomysial } \\
\text { antibody IgA }\end{array}$ & $1 / 1000$ & $1 / 1000$ \\
\hline $\begin{array}{l}\text { Anti-endomysial } \\
\text { antibody IgA }\end{array}$ & $1 / 2150$ & $1 / 2560$ \\
\hline IgA serum & $67 \mathrm{mg} / \mathrm{dl}$ & $50 \mathrm{mg} / \mathrm{dl}$ \\
\hline
\end{tabular}

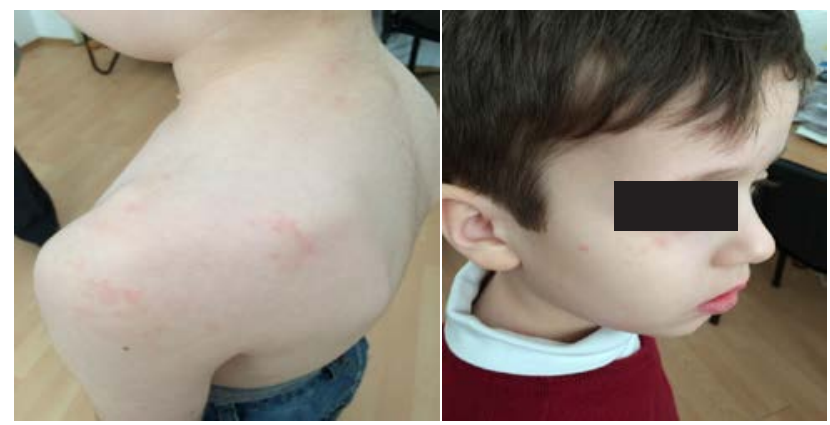

Figure 2. Pacients with celiac diseses and dermatitis herpetiformis

Frequency combination of celiac disease with other autoimmune disease [6,7] called for the exclusion of other possible coexisting conditions, so 4 patients were further diagnosed with autoimmune thyroiditis. All patients had normal thyroid function and none of the patients had not been diagnosed with thyroid disfunction before the onset of celiac disease.

\section{Case presentation}

Patient M.L., male sex, aged 7 years and 8 months, was presented to the Pediatric Clinic of Clinical Emergency County Hospital Constanta for an evaluation of alopecia areata (Figure 3).

History of alopecia shows that it's onset was noticed two years ago, progressing over time to complete loss of hair on the body.

From family history we mention: grandfather with type 2 diabetes.

From personal history we mention: 2nd child, gestational age 8 months and 1 week, natural birth, weight at birth $=2900 \mathrm{~g}$, breastfeeding to 2 years, solid food started to 6 months with fruit (banana), first introduction of gluten in the diet at 7 months.

From medical history of the patient we note: Down syndrome (genetically confirmed), Tetralogy of Fallot operated, bilateral testicular ectopia operated (2013)

At physical examination we found:

- $\quad$ specific phenotype for Down syndrome

- alopecia areata

- enamel hypoplasia

- gingival inflammation

- nail dystrophy

- systolic heart murmur III / VI degree

- height $=120 \mathrm{~cm}$ (P75-90\% on growth charts for boys with Down Syndrome)

- $\quad$ weight $=18,5 \mathrm{~kg}(\mathrm{P} 10 \%$ on growth charts for boys with Down Syndrome)

Because celiac disease may be associated with Down syndrome, Anti-tissue Transglutaminase Antibody $\operatorname{IgA}$ and $\operatorname{IgG}$ were asked initially, along with total IgA (to exclude a selective IgA- deficiencynormal result) anti-thyroid peroxidase antibodies, both antibodies with values much higher than normal (Table III). 


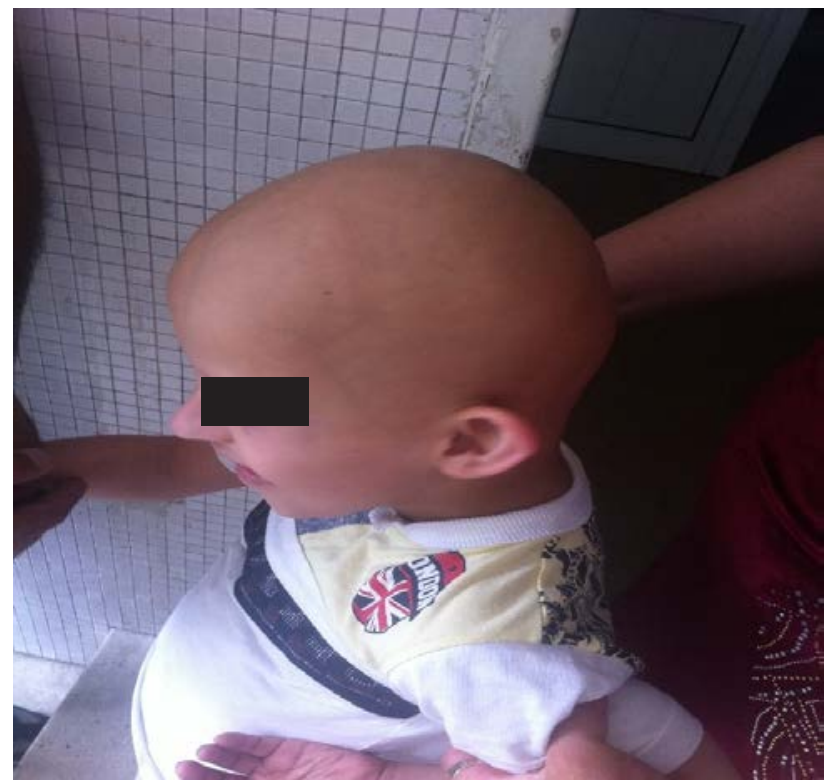

Figure 3. Child with Down syndrome, celiac disease and alopecia

Table III. Serology for associated autoimmunnity

\begin{tabular}{|l|r|}
\hline $\begin{array}{l}\text { Anti-tissue Transglutaminase } \\
\text { Antibody IgA }\end{array}$ & $>200 \mathrm{U} / \mathrm{ml}$ \\
\hline $\begin{array}{l}\text { Anti-tissue Transglutaminase } \\
\text { Antibody IgG }\end{array}$ & $116.6 \mathrm{U} / \mathrm{ml}$ \\
\hline Anti-thyroid peroxidase antibodies & $>600 \mathrm{U} / \mathrm{ml}$ \\
\hline Antithyroglobulin antibodies & $97 \mathrm{UI} / \mathrm{ml}$ \\
\hline TSH & $4.12 \mu \mathrm{UI} / \mathrm{ml}$ \\
\hline FT4 & $15.1 \mathrm{pmol} / \mathrm{l}$ \\
\hline
\end{tabular}

To confirm the diagnosis have been performed from another sample of blood other specific antibodies, IgA anti-endomysium, found in high titer (TableIV).

Table IV. Specific Anti-endomysial antibodies

\begin{tabular}{|l|l|}
\hline Deamidated gliadin antibodies IgG & $9.1 \mathrm{mg} / \mathrm{dl}$ \\
\hline Anti-endomysial antibodies IgA & $1 / 320$ titer \\
\hline Anti-endomysial antibodies IgG & $1 / 10$ titer \\
\hline
\end{tabular}

\section{Conclusion:}

Recognizing the complexity of the clinical presentation of celiac disease, helps for diagnose and treatment measures of other associated diseases, even if gastrointestinal symptoms may be missing. It seems to be justified as a screening method to determine a population screening for immunoglobulin A antibodies to tissue transglutaminase and IgA total serum level followeds in selective cases by Anti-tissue Transglutaminase Antibody IgG, antiendomysial antibodies, gliadin antibodies IgA and $\mathrm{IgG}$ and intestinal biopsia.

\section{References}

1. Schuppan, D. (2000). Current concepts of celiac disease pathogenesis. Gastroenterology. 119(1), 234-242.

2. Husby, S., Koletzko, S., Korponay-Szabó, I.R., Mearin, M.L., Phillips, A., Shamir, R., ... European Society for Pediatric Gastroenterology, Hepatology, and Nutrition. (2012). European Society for Pediatric Gastroenterology, Hepatology, and Nutrition Guidelines for the Diagnosis of Coeliac Disease. Journal of Pediatric Gastroenterology and Nutrition, 54(1), 136-60. http://doi.org/10.1097/MPG.0b013e31821a23d0

3. Krzewska, A. \& Ben-Skowronek, I. (2016). Effect of Associated Autoimmune Diseases on Type 1 Diabetes Mellitus Incidence and Metabolic Control in Children and Adolescents. BioMed Research International, 2016, 1-12. http://doi.org/10.1155/2016/6219730

4. Cerutti, F., Bruno, G., Chiarelli, F., Lorini, R., Meschi, F., Sacchetti, C. \& Diabetes Study Group of the Italian Society of Pediatric Endocrinology and Diabetology. (2004). Younger age at onset and sex predict celiac disease in children and adolescents with type 1 diabetes: an Italian 
multicenter study. Diabetes Care, 27(6), 1294 98. Retrieved from http://www.ncbi.nlm.nih. gov/pubmed/15161778

5. Sud, S., Marcon, M., Assor, E., Palmert, M., Daneman, D. \& Mahmud, F. (2010). Celiac Disease and Pediatric Type 1 Diabetes: Diagnostic and Treatment Dilemmas. International Journal of Pediatric Endocrinology, 2010(1), 161285. http://doi.org/10.1155/2010/161285

6. Bakker, S.F., Tushuizen, M.E., von Blomberg, B.M.E., Bontkes, H.J., Mulder, C.J. \& Simsek, S. (2016). Screening for coeliac disease in adult patients with type 1 diabetes mellitus: myths, facts and controversy. Diabetology \& Metabolic Syndrome, 8(1), 51. http://doi.org/10.1186/ s13098-016-0166-0

7. Skyler, J.S. (2013). Primary and secondary prevention of Type 1 diabetes. Diabetic Medicine, 30(2), 161-69. http://doi.org/10.1111/dme.12100 